CORRUPTION ERADICATION COMMSSION'S AUTHORITY ON CRIMINAL ACT OF CORRUPTION THAT INCUR LOSSES TO THE STATE'S FINANCE

\title{
KEWENANGAN KOMISI PEMBERANTASAN KORUPSI DALAM PENYITAAN TERHADAP TINDAK PIDANA KORUPSI YANG MERUGIKAN KEUANGAN NEGARA
}

\author{
Fijar Alifyansyah*, Dadang Suprijatna**, Inayatullah Abd Hasyim*** \\ Pinjun13@gmail.com
}

(Diterima pada: 01-02-2019 dan dipublikasikan pada:01-03-2019 )

\begin{abstract}
Corruption is an Extraordinary Crime does not only incur losses to the States financially but also violate people's social and economic rights therefore the eradication is conducted ectraordinarily. Establishment of Corruption Eradication Commission (KPK) as a special institution uses an extraordinary law enforcement and different authority with the Criminal Procedure Code, especially in confiscation. However, the rules about the confiscation is often get report because there is no limitation of it. The method that used in this research is legally normative. In addition, the purpose of this research is to review and conduct legal analysis on KPN's authority in conducting the confiscation of the corruption criminal act that incur losses to the States financially and scope of the confiscation itself.
\end{abstract}

Keywords: Corruption, Extraordinary, Corruption Eradication Commission, Confiscation

\begin{abstract}
ABSTRAK
Korupsi merupakan Extra Ordinary Crime, tidak hanya merugikan keuangan negara tetapi juga pelanggaran terhadap hak-hak sosial dan ekonomi masyarakat secara luas, sehingga pemberantasan korupsi dilakukan secara luar biasa. Pembentukan Komisi Pemberantasan Korupsi (KPK) sebagai Lembaga khusus menggunakan metode penegakan hukum secara luar biasa serta kewenangan yang berbeda dengan KUHAP, khususnya pada penyitaan. Namun ketentuan penyitaan tersebut seringkali mendapat laporan dikarenakan tidak adanya batasan dalam pelaksanaan penyitaan. Metode pendekatan yang digunakan dalam penelitian ini yaitu yuridis normatif. Adapun Penelitian ini bertujuan untuk meninjau dan melakukan analisis hukum bagaimana kewenangan KPK dalam pelaksanaan penyitaan tindak pidana korupsi yang merugikan keuangan negara serta Ruang lingkup dalam penyitaan tersebut.
\end{abstract}

Kata Kunci : Korupsi, Extra Ordinary Crime, KPK, Penyitaan 


\section{Buku}

\section{DAFTAR PUSTAKA}

Alpiner Sinaga, Korupsi Bias dan Strategi Penyidikan, Badan Reskrim Mabes Polri, Jakarta, 2005.

Ikhwan Fahroji, Hukum Acara Pidana Korupsi, Setara Press, Malang, 2016.

Indriyanto Seno Adji, Korupsi dan Permasalahannya, Diadit Media Pers, Jakarta, 2012

Martin Roestamy et al. Metode Penelitian dan Penulisan Hukum. 2015. Bogor : Unida Press.

R. Diyatmiko Soemodihardjo, Mencegah dan memberantas korupsi, mencermati dinamiknya di Indonesia, Prestasi Pustaka Publisher, Jakarta, 2008.

\section{Jurnal}

Indonesia Corruption Watch, Penerapan unsur merugikan keuangan negara dalam delik tindak pidana korupsi, Yayasan Lembaga Hukum Indonesia, Jakarta, 2014.

Mahkamah Konstitusi Republik Indonesia, Jurnal Mahkamah Konstitusi Vol 9. No.2, Jakarta, 2012.

Dadang Suprijatna, Konvensi Ketatanegaraan dalam Praktik Konstitusi Indonesia, Jurnal Hukum De'Rechtsstaat Volume 1 Nomor 1, FH Unida, Bogor, 2015.

\section{Laporan Tahunan}

Laporan Tahunan KPK Tahun 2016

Laporan Tahunan KPK Tahun 2017

\section{Sumber Elektronik}

https://www.kpk.go.id/id/tentang-kpk

https://acch.kpk.go.id/id/artikel/riset-publik/tata-laksana-benda-sitaan-dan-barang-rampasan

https://acch.kpk.go.id/id/component/content/article/aset-koruptor-mengapa-harus-disita 